Pobrane z czasopisma Annales H - Oeconomia http://oeconomia.annales.umcs.pl Data: 26/04/2023 13:51:46

DOI:10.17951/h.2017.51.2.39

\begin{tabular}{lcl}
\hline \multicolumn{1}{c}{ A N N A L E S } \\
UNIVERSITATIS MARIAE CURIE-SKŁODOWSKA \\
LUBLIN - POLONIA \\
VOL. LI, 2 \\
\hline
\end{tabular}

Maria Curie-Skłodowska University in Lublin, Marketing Department

ILONA BONDOS

ilona.bondos@poczta.umcs.lublin.pl

\title{
Multichanneling or Channel Elimination? The Empirical Results of E-Channel Migration Strategy
}

Wielokanałowość czy eliminacja kanału?

Wyniki badania rezultatów strategii migracji klientów do e-kanału

Key words: e-channel migration; multichanneling; channel elimination; service distribution

Słowa kluczowe: migracja do e-kanału; wielokanałowość; eliminacja kanału; dystrybucja usług

JEL codes: M31; M21; L81

\section{Introduction}

According to Neslin et al. [2006], one of the most dramatic trends in the shopping environment has been the proliferation of channels through which customers can interact with firms. An optimal channel will often differ for the various stages of the buying process - customers may prefer different channels for post-purchase activities than the channels for pre-purchasing activities [Van Bruggen et al. 2010, p. 331].

In this study, the author takes a customer-centric view of multichannel strategies and investigates customer responses toward e-channel management strategies at the post-purchase stage for the delivery of telecommunications service. The goal of this paper is to answer the following research question: How do customers respond to different e-channel migration strategies? The answer to this question will enable the development of a kind of hierarchy of migration strategy in terms of consequences (customers' emotions and behavioral intentions). 
This paper proceeds as follows: first, the theoretical background and prior research on channel elimination and customer migration strategy are presented. Then, the author presents her research approach - content of scenarios, research sample and selected data on the reliability of measurement. Next, the author outlines empirical results and she concludes with a discussion of managerial implications, limitations, and avenues for future research.

\section{Theoretical background}

In their paper, Neslin et al. [2006] look at marketing channel as customer contact points, or a medium through which the firm and the customer interact. One of the main goals is to create an overall retail customer experience [Verhoef et al. 2015, p. 176; Lemon and Verhoef 2016, p. 80; Van Bruggen et al. 2010, p. 331]. Offering multiple channels of transaction with a customer is perceived as crucial for sustained growth in the current competitive environment [Venkatesan et al. 2007, p. 114]. Researchers have identified specific goals of using channels: economic, self-affirmation, symbolic meaning, socialization and experiential and routine or script maintenance goals [Balasubramanian et al. 2005]. As indicated by Neslin and Shankar [2009], forcing customers to use certain channels may turn them off because it steers them to use channels that are contrary to their preferences. In this context it is worth pointing to the differences in the perception of individual channels by different customers generations [Lipowski 2016, p. 203]. Researchers suggest two extreme variants, the first one is that consumers might behave homogeneously, using all channels for the same reasons. In this case a multichannel strategy is essentially mass marketing. The second extreme - specific segments might align with specific channels. In this case, marketers must understand the characteristics or covariates of these segments to determine how to design and target their channels [Konus et al. 2008, p. 398]. In their paper, Neslin and Shankar [2009] present a customer management-based framework that structures the process by which the firm can develop and implement a multichannel strategy, and to use the framework to identify key customer management issues to be addressed. Three of these issues are strictly related to the research question contained in the article:

- Which channels should be employed?

- What should be the functions of each channel?

- Should customers be "right-channeled" and if so - how?

Particularly noteworthy is the last question about the need of right-channeling, which means making sure that right customers utilize the right channels; it might occur naturally if customer segments self-select into the channels they prefer [Blattberg et al. 2008, p. 667]. Neslin and Shankar [2009, p. 75] ask specific questions about the possibility of causing by right-channeling the resentment and jealousy among customers and "regular" customers' resentment on "preferred" consumers. The key problem is 
the risk of destroying customer retention by right-channeling. Therefore, the crucial question is: Can right-channeling be achieved through incentives and self-selection rather than strong-armed methods? [Neslin and Shankar 2009, p. 75]. That question is all the more justified, the more true is the view that the consumer's channel choice probabilities may change over time (the so-called nonstationarity) [Thomas and Sullivan 2005, p. 240]. According to Dholakia et al. [2010, p. 88], the growing number of multichannel studies suggest that channel choice is not static but changes over time, as consumers migrate from one channel to another. Myers et al. [2004] are optimistic about the possibility of right-channeling. Researchers claim that having the right strategy and transition plan, companies can migrate their customers to different channels while still keeping the customers happy. In their paper, Ansari et al. [2008, p. 62,71] note that channel migration affects firm profit through its influence on cost and revenue. However, in their study they demonstrate that migration can be negatively associated with long-term purchase patterns and for this reason there should not be explicitly stated on unqualifiedly positive character of migration strategy.

As indicated by Trampe et al. [2014, p. 258], there is a distinction between voluntary and forced customer e-channel migration strategies. According to these researchers, the effects of e-channel migration strategies on customers are neglected in the research literature. Forced migration strategy actually means the elimination of a specific channel (channel origin), it is, therefore, in opposition to the whole idea of omnichanneling [Lipowski and Bondos 2016, p. 79]. This type of migration strategy should lead to channel switching, but it has been claimed that there is a great risk of negative consequences on the consumer side influencing the situation of the service provider [Bondos 2016a, p. 14]. In the context of the radical variants migration strategy for e-channel is worth paying attention to the channel adoption duration. Venkatesan et al. [2007, p. 114] emphasize the issue of the time a customer takes to adopt an additional channel with marketing accountability. According to these authors, the effects of concentration on marketing accountability is better allocation of marketing resources at each business cycle to individual customers, products, and channels to maximize return on marketing investments. Avery et al. [2012, p. 104] also pay attention to time aspect - according to them, some channel capabilities are immediately apparent to consumers while others must be learned, resulting in different short- and long-term effects. These researchers argue that firsttime and repeat customers have different shopping goals and, therefore, differentially value channel capabilities. In order to counteract negative consequences of a forced strategy, service providers may implement migration strategies based on incentives - positive (rewards-based strategy) or negative (punishments-based strategy). As Trampe et al. [2014, p. 258] note, incentive-based strategies are a kind of reinforced strategies and their effects are likely to have a different impact on customers than forced or voluntary e-channel migration strategies. It is also worth noting that winwin incentives do not always exist [Myers et al. 2004]. There is no doubt that these positive/negative stimuli also generate cost and risk for implementer. 
It appears, therefore, that the most favorable for the consumer option of migration strategy is voluntary migration. This migration option corresponds to the essence of multichanneling. In multichannel environment, it is important to assess and reduce the risk of channels cannibalization and, at the same time, to benefit from synergy between the channels [Kollmann et al. 2012, p. 189; Deleersnyder et al. 2002, p. 346].

\section{Study results}

In her study, the author applied the scenario approach. Unlike the original research approach [Trampe et al. 2014], this study refers to telecommunications services at the stage of post-purchase service (the original investigation related to the phase of purchase banking services). The study was conducted on a sample of 345 consumers (students of business studies). Content of scenario was as follows:

Telecommunications service provider - mobile phone, which you are a user - announced that from August 1, 2016 will launch an Internet channel technical customer service - all day Internet chat. At the same time, a service provider announces that a new service channel will be available alongside existing channels - offline stores and call center. However, you should keep in mind the change in the existing rules of customer service:

- Scenario A (financial rewards): the introduction of discount. If you choose not to use for the maintenance of telephone and stationary service channel and decide on the online channel (chat), the amount of 10 PLN will be subtracted from your cell phone bill for the last period of each quarter.

- Scenario B (financial punishments): the introduction of quarterly administration fee. If you decide to continue using the phone or offline channel in case of technical service, the amount of 10 PLN will be added to your cell phone bill for the last period of each quarters.

- Scenario C (forced migration): from 1 December 2016, the existing service channels are no longer available in the field of technical customer service; the only possibility is to use the online channel;

- Scenario D (voluntary migration): a new channel technical service will be available alongside existing channels.

Statements used in the study of consumer attitudes to be redirected the Internet channel were taken from literature. Table 1 presents used references and value of Cronbach's alpha as a measure of the reliability measurement. 
Pobrane z czasopisma Annales H - Oeconomia http://oeconomia.annales.umcs.pl

Data: 26/04/2023 13:51:46

MULTICHANNELING OR CHANNEL ELIMINATION? THE EMPIRICAL RESULTS OF E-CHANNEL...

Table 1. Theoretical constructs used in the study

\begin{tabular}{|l|c|c|c|c|c|c|}
\hline \multirow{2}{*}{ Latent variable } & \multirow{2}{*}{$\begin{array}{c}\text { Number } \\
\text { of items }\end{array}$} & \multicolumn{2}{|c|}{ Cronbach's alfa for each migration strategy } & \multicolumn{2}{|c|}{ Literature source } \\
\cline { 3 - 6 } & Voluntary & Forced & Rewards & Punishments & \\
\hline Positive WOM & 4 & 0.90 & 0.93 & 0.94 & 0.86 & $\begin{array}{l}\text { [Yang et al. 2015], [San-Martín } \\
\text { et al. 2015] }\end{array}$ \\
\hline $\begin{array}{l}\text { Perceived limited } \\
\text { freedom }\end{array}$ & 3 & 0.86 & 0.85 & 0.88 & 0.88 & [Trampe et al. 2014] \\
\hline Reactance & 2 & 0.66 & 0.60 & 0.68 & 0.66 & [Trampe et al. 2014] \\
\hline Purchase intention & 3 & 0.72 & 0.70 & 0.84 & 0.84 & [Zielke 2010] \\
\hline
\end{tabular}

Source: Author's own study.

The intention of the author was to develop a hierarchy of migration strategies according to its positive results for service supplier - customers' emotions and behavioral intentions. Figure 1 shows the average values that refer consumer response for each of the four analyzed e-channel migration strategy.

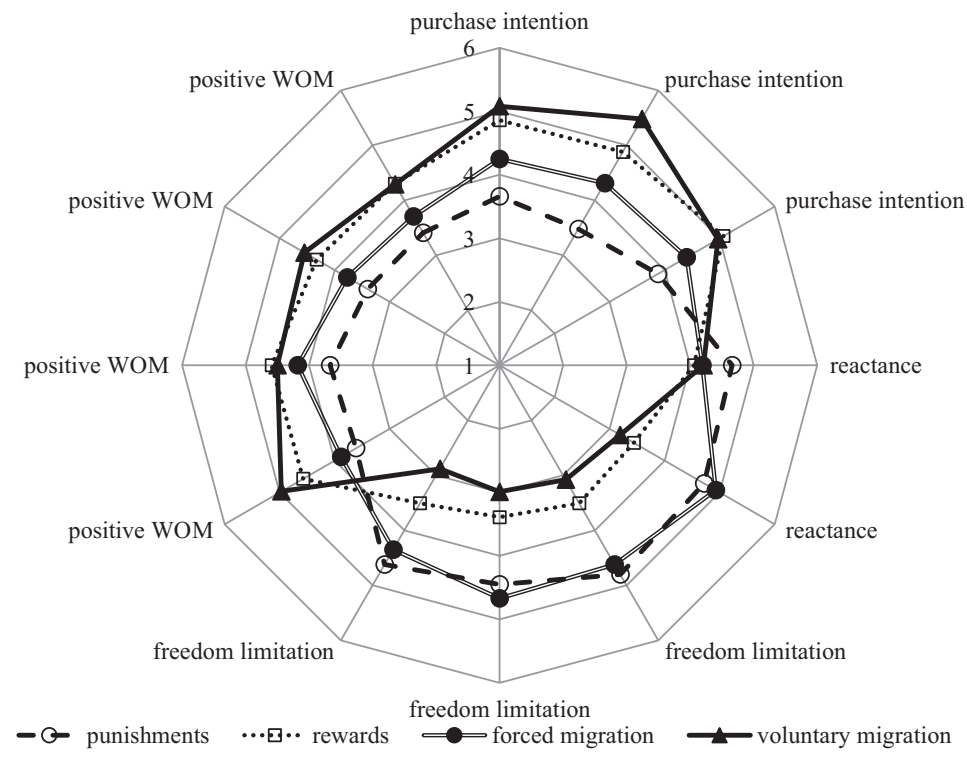

Figure 1. Consumer reactions to different migration strategies

Note: Scale from 1 ("strongly disagree") to 7 ("strongly agree").

Source: Author's own study.

Based on the study results it was possible to build a kind of hierarchy of migration strategy in terms of consequences. Taking into account statistically significant differences, first place occupies voluntary migration, the second place is for strategy based on rewards (particularly noteworthy is the convergence of reactance 
and positive WOM, other elements of customer attitudes were in favor of voluntary migration). And the last place in the classification take - equivalently - migration strategy based on punishment and forced migration strategy. Based on the obtained values it was impossible to clearly indicate the superiority of one strategy over the other - purchase intention was statistically higher in case of forced migration, this strategy also generates greater propensity to recommend the offer. But the issue of reactance and perceived freedom limitation were ambiguous in case of these two strategies.

\section{Conclusions}

In addition to contributing to overall understanding of customer response to e-channel migration strategy, this research also suggests important managerial implications. General recommendation refers to the need for a high awareness of the consequences of each option of e-channel migration strategy. Managers should recognize that a forced e-channel migration strategy and punishments-based strategy can generate the most negative consequences on customer attitudes. Multichannel service providers are obliged to consider how to mitigate such negative customers' emotions and behavioral intentions. As Trampe et al. [2014, p. 266] note, punishments should not be used - carrots are more effective than sticks. For this reason, managers should give more attention to the future consequences of today's decision to migrate customers to the (seemingly?) less expensive channel. It is possible that a favorable solution would be tried to engage customers in their migration to e-channel - e.g. to offer the customer the freedom to choose the time to migrate to the online channel within a specified period (e.g. within 10 months) [Bondos, 2016b]. Such actions would be in clear opposition to the perceived by the customers restrictions on their freedom during the implementation of a strategy (forced and based on negative incentives). A key challenge for service providers seems to be a balance between these different migration strategies. On the one hand, important are the costs of customer service within the strategy positively evaluated by customers, on the other hand, there is a real risk of customers churn and negative WOM.

Although the results of this study have useful implications, some limitations must be considered. First, research approach. Researchers have noted that participants in experimental studies may alter their actions to conform to the behavior that they believe the experimenter desires [Levitt and List 2007, p. 350]. Other critical assumption underlying the interpretation of data from scenario experiments is that the results gained from this method can be extrapolated to a real-world setting [Kim and Jang 2014, p. 125]. Second limitation refers to the fact that the reported experiment focuses on one specific context (the telecommunications service industry). Finally, limitation also applies to used research sample - undoubtedly, you cannot underestimate common objections, namely that student participant pools are unrepresentative 
and that sample sizes are small [Falk and Heckman 2009, p. 535]. Author is also aware that several issues that may be important, as customer responses to e-channel migration strategy, do not appear in this research.

\section{Bibliography}

Ansari, A., Mela, C.F., Neslin, S.A., Customer Channel Migration, “Journal of Marketing Research”, vol. 45, no. 1, 2008, pp. 60-76.

Avery, J., Steenburgh, T.J., Deighton, J., Carvella, M., Adding Bricks to Clicks: Predicting the Patterns of Cross-Channel Elasticities over Time, "Journal of Marketing”, vol. 76, no. 3, 2012, pp. 96-111.

Balasubramanian, S., Raghunathan, R., Mahajan, V. Consumers in a Multichannel Environment: Product Utility, Process Utility, and Channel Choice, "Journal of Interactive Marketing”, vol. 19, no. 2, 2005, pp. 12-30.

Blattberg, R.C., Kim, B.-D., Neslin, S.A., Database Marketing: Analyzing and Managing Customers, Springer, New York 2008.

Bondos, I., E-Channel Migration Strategy - A Double-Edged Sword?, "Проблеми економіки та управління", 847, 2016а.

Bondos, I., Prosumeryzm i strategia migracji klientów do kanalu online-czy mają coś wspólnego?, "Zeszyty Naukowe WSES w Ostrołęce", vol. 4, no. 23, 2016b, pp. 313-322.

Deleersnyder, B., Geyskens, I., Gielens, K., Dekimpe, M.G., How Cannibalistic Is the Internet Channel? A Study of the Newspaper Industry in the United Kingdom and the Netherlands, "International Journal of Research in Marketing", vol. 19, no. 4, 2002, pp. 337-348.

Dholakia, U.M., Kahn, B.E., Reeves, R., Rindfleisch, A., Stewart, D., Taylor, E., Consumer Behavior in a Multichannel, Multimedia Retailing Environment, "Journal of Interactive Marketing”, vol. 24, no. 2, 2010, pp. 86-95.

Falk, A., Heckman, J.J. Lab Experiments Are a Major Source of Knowledge in the Social Sciences, "Science", vol. 326, 2009, pp. 535-538.

Kim, J.-H., Jang, S., A Scenario-Based Experiment and a Field Study: A Comparative Examination for Service Failure and Recovery, "International Journal of Hospitality Management", vol. 41, 2014, pp. 125-132.

Kollmann, T., Kuckert, A., Kayser, I., Cannibalization or Synergy? Consumers' Channel Selection in Online-Offline Multichannel Systems, "Journal of Retailing and Consumer Services”, vol. 19, no. 2, 2012, pp. 186-194.

Konus, U., Verhoef, P.C., Neslin, S.A., Multichannel Shopper Segments and Their Covariates, "Journal of Retailing”, vol. 84, no. 4, 2008, pp. 398-413.

Lemon, K.N., Verhoef, P.C., Understanding Customer Experience Throughout the Customer Journey, "Journal of Marketing", vol. 80, no. 6, 2016, pp. 69-96.

Levitt, S.D., List, J.A., Viewpoint: On the Generalizability of Lab Behaviour to the Field, "Canadian Journal of Economics", vol. 40, no. 2, 2007, pp. 347-370.

Lipowski, M., Bondos, I., Omnikanałowość - czy rynek zweryfikuje koncepcję teoretyczną?, "Kwartalnik Naukowy Organizacja i Zarządzanie”, no. 1(33), 2016, pp. 71-82.

Lipowski, M. Multikanałowość dystrybucji ustug w gospodarce sieciowej, Wydawnictwo UMCS, Lublin 2016.

Myers, J.B., Pickersgill, A.D. and van Metre, E.S., Steering Customers to the Right Channels, "McKinsey Quarterly", vol. 3, no. 1, 2004.

Neslin S.A., Shankar, V., Key Issues in Multichannel Customer Management: Current Knowledge and Future Directions, "Journal of Interactive Marketing”, vol. 23, no. 1, 2009, pp. 70-81. 
Neslin, S.A., Grewal, D., Leghorn, R., Venkatesh, S., Teerling, M.L., Thomas, J.S., Verhoef, P.C., Challenges and Opportunities in Multichannel Customer Management, "Journal of Service Research", vol. 9, no. 2, 2006, pp. 95-112.

San-Martín, S., Prodanova, J., Jiménez, N., The Impact of Age in the Generation of Satisfaction and WOM in Mobile Shopping, "Journal of Retailing and Consumer Services", vol. 23, 2015, pp. 1-8.

Thomas, J., Sullivan, U.Y., Managing Marketing Communications with Multichannel Customers, "Journal of Marketing”, vol. 69, no. 4, 2005, pp. 239-251.

Trampe, D., Konuş U., Verhoef, P.C., Customer Responses to Channel Migration Strategies Toward the E-Channel, "Journal of Interactive Marketing", vol. 28, 2014, pp. 257-270.

Van Bruggen, H.G., Antia, K.D., Jap, S.D., Reinartz, W.J., Palls, F. Managing Marketing Channel Multiplicity, "Journal of Service Research", vol. 13, no. 3, 2010, pp. 331-340.

Venkatesan, R., Kumar, V., Ravishanker, N., Multichannel Shopping: Causes and Consequences, "Journal of Marketing", vol. 71, no. 2, 2007, pp. 114-132.

Verhoef, P.C., Kannanb, P.K., Inman, J.J., From Multi-Channel Retailing to Omni-Channel Retailing: Introduction to the Special Issue on Multi-Channel Retailing, "Journal of Retailing", vol. 91, no. 2, 2015, pp. 174-181.

Yang, K., Li, X., Kim, H.J., Kim, Y.H., Social Shopping Website Quality Attributes Increasing Consumer Participation, Positive EWOM, and Co-Shopping: The Reciprocating Role of Participation, "Journal of Retailing and Consumer Services", vol. 24, 2015, pp. 1-9.

Zielke, S., How Price Image Dimensions Influence Shopping Intentions for Different Store Formats, "European Journal of Marketing", vol. 44, no. 6, 2010, pp. 748-770.

\section{Multichanneling or Channel Elimination? The Empirical Results of E-Channel Migration Strategy}

In this study, the author takes a customer-centric view of multichannel strategies and investigates customer responses toward e-channel migration strategies at the post-purchase stage for the delivery of telecommunications service. The study with a scenario approach was conducted on a sample of 345 consumers (students of business studies). The goal of this paper is to answer the following research question: How do customers respond to different e-channel migration strategies? Four strategies were included: voluntary migration, forced labor, based on punishment and rewards. The effect of the answer to this question was a kind of hierarchy of migration strategy in terms of consequences (customers' emotions and behavioral intentions). In the final part of the article, the practical implications and limitations of results have been formulated.

\section{Wielokanałowość czy eliminacja kanału? Wyniki badania rezultatów strategii migracji klientów do e-kanału}

W badaniu uwzględniono perspektywę konsumenta w odniesieniu do obsługi wielokanałowej, analizowano reakcje konsumentów na strategie migracji na etapie obsługi pozakupowej usług telekomunikacyjnych. Wykorzystano podejście scenariuszowe, próba badawcza liczyła 345 konsumentów (studentów kierunków ekonomicznych). Celem artykułu była odpowiedź na pytanie badawcze: Jak konsumenci reagują na poszczególne strategie migracji do e-kanału. Uwzględnione zostały cztery strategie: migracja dobrowolna, przymusowa, oparta na karach i nagrodach. Efektem analizy była hierarchia strategii z uwzględnieniem konsekwencji w zachowaniu klientów (emocje oraz intencje behawioralne). W końcowej części artykułu sformułowano praktyczne implikacje oraz ograniczenia wyników. 